

\title{
VALIDATED RP-HPLC METHOD FOR QUANTIFICATION OF GASTRODIN IN ETHANOLIC EXTRACT FROM THE PSEUDOBULBS OF Grammatophyllum speciosum Blume
}

\author{
(Validasi Kaedah FT-KCPT bagi Kuantifikasi Gastrodin di dalam Ekstrak Etanolik dari \\ Pseudobulbs Grammatophyllum speciosum Blume)

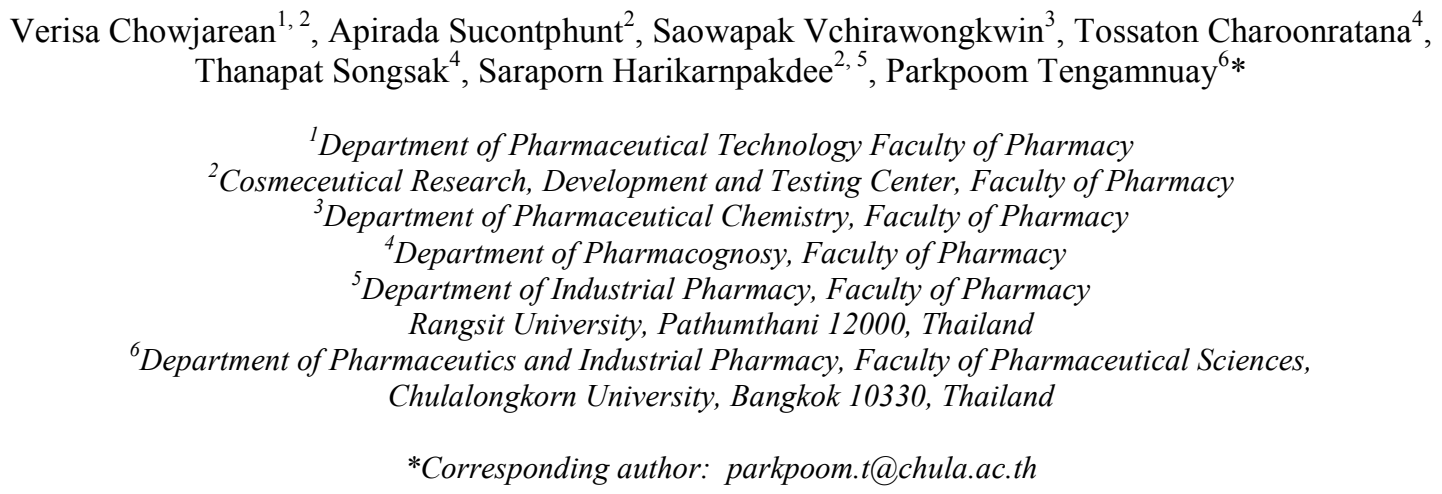

Received: 7 September 2017; Accepted: 7 February 2018

\begin{abstract}
A reversed phase-high performance liquid chromatography-diode array detector (RP-HPLC-DAD) method was developed to determine the amount of gastrodin, the major active component of Grammatophyllum speciosum pseudobulbs. A previous study suggested that the ethanolic extract of $G$. speciosum had a potential to encourage stemness of keratinocytes. Therefore, in order to determine the quality of $G$. speciosum ethanolic extract, the quantitative analysis of gastrodin should be validated. The optimized RP-HPLC condition was achieved within $18 \mathrm{~min}$, using a column, Inertsil ODS-3 (4.6 x $150 \mathrm{~mm}, 5 \mu \mathrm{m})$. The mobile phase consisted of a mixture of water: acetonitrile with a gradient from 1:99 to 100:0 in 14 minutes and keep constant at 1:99 for 4 minutes. The flow rate was $1.7 \mathrm{~mL} / \mathrm{min}$ with the monitored UV wavelength of $220 \mathrm{~nm}$. Gastrodin was eluted at the retention time of 6.5 minutes. The calibration curve of gastrodin at the concentration of $10-100 \mu \mathrm{g} / \mathrm{mL}$ showed good linearity $\left(\mathrm{r}^{2}=\right.$ 0.999). In addition, the intraday and interday precisions of gastrodin were 1.05 and $0.38 \%$, respectively. The percentage recovery was within $99.3-101.5 \%$. Average gastrodin contents in 3 samples were $55.52-58.12 \mathrm{mg} / \mathrm{g}$. The results indicate that this method can be utilized to control the quality of $G$. speciosum extract.
\end{abstract}

Keywords: gastrodin, Grammatophyllum speciosum, reversed-phase high performance liquid chromatography, quantification

\footnotetext{
Abstrak

Kaedah fasa terbalik-kromatografi cecair berprestasi tinggi-pengesan susunan diod (FT-KPCT-PSD) telah dibangunkan untuk menentukan jumlah kandungan gastrodin, komponen aktif utama bagi pseudobulbs Grammatophyllum speciosum. Kajian sebelumnya mencadangkan ekstrak etanolik terhadap G. speciosum mempunyai potensi menguatkan stem keratinocytes. Oleh demikian, bagi menentukan kualiti ekstrak etanolik G. speciosum, analisis kuantitatif terhadap gastrodin perlu ditentusahkan. Keadaan optimum FT-KCPT telah dicapai pada minit ke 18, mengunakan turus Inertsil ODS-3 (4.6 x $150 \mathrm{~mm}, 5 \mu \mathrm{m})$. Fasa bergerak mengandungi campuran air:asetonitril dengan cerunan dari 1:99 hingga 100:0 bagi tempoh 14 minit dan kekal malar pada 1:99 selama 4 minit. Kadar aliran ialah $1.7 \mathrm{~mL} / \mathrm{min}$ dengan pemerhatian panjang gelombang UV pada $220 \mathrm{~nm}$. Gastrodin terelusi pada masa tahanan ialah minit ke 6.5. Lengkung kalibrasi gastrodin pada aras kepekatan $10-100 \mu \mathrm{g} / \mathrm{mL}$ telah
} 


\section{Chowjarean et al: VALIDATED RP-HPLC METHOD FOR QUANTIFICATION OF GASTRODIN IN ETHANOLIC EXTRACT FROM THE PSEUDOBULBS OF Grammatophyllum speciosum Blume}

menunjukkan kelinearan yang baik $\left(\mathrm{r}^{2}=0.999\right)$. Kejituan intra-hari dan inter-hari telah dicapai masing-masing pada 1.05 dan $0.38 \%$. Peratusan perolehan semula berada di dalam julat $99.3-101.5 \%$. Purata kandungan gastrodin di dalam 3 sampel adalah 55.52 - $58.12 \mathrm{mg} / \mathrm{g}$. Keputusan ini menunjukkan kaedah boleh digunapakai untuk mengawal kualiti G. speciosum yang diekstrak.

Kata kunci: gastrodin, Grammatophyllum speciosum, fasa terbalik kromatografi cecair berprestasi tinggi, kuantifikasi

\section{Introduction}

Grammatophyllum speciosum Blume or Waan-Phet-Cha-hueng (Thai name) is a plant in Orchidaceae family. It is also known as giant orchid, tiger orchid, sugar cane orchid or queen of the orchid. This gigantic orchid is typically found in the tropical rainforests of Southeast Asia such as Thailand, Malaysia, Indonesia, and Philippines [1, 2]. In Thai traditional medicine, its root is utilized as a treatment for centipede and scorpion venom, while its trunk, when blended with alcohol, is utilized to treat sores. The previous research found that the liquid extract of $G$. speciosum at the concentration of $0.706 \mathrm{mg} / \mathrm{mL}$ was effective in treating scorpion venom (Heterometrus laoticus) with a $23 \%$ cure rate [3]. Phytochemical investigation by Sahakitpichan et al. [2], reported new compounds isolated from the methanolic extract of the fresh pseudobulbs of G. speciosum which included glucosyloxybenzyl derivatives of (R)2-benzylmalic acid and of (R)-eucomic acid, grammatophyllosides A-C, and a new phenolic glucoside, grammatophylloside D, cronupapine, vandateroside II, gastrodin, vanilloloside, orcinolglucoside, and isovitexin.

Gastrodin (Figure 1), a phenolic glycoside [p-hydroxymethylphenyl- $\beta$-D-glucopyranoside] found as a major active component in G. speciosum, is a potent antioxidant. Gastrodin was also found to function as anti-apoptotic activities in brain areas [4], a memory enhancer [5, 6], as well as having anti-convulsant [7], anti-cell death [8], antiAlzheimer's disease [9], anti-Parkinson's disease activities [10], as well as protective effects against osteoporosis linking to a reduction in reactive oxygen species [11]. In addition, G. speciosum ethanolic extract was reported to have a potential to increase stem cell phenotypes of human keratinocytes. Moreover, the extract also had an ability to protect the cells against superoxide anion-induced cell death [12]. As gastrodin is a major active compound in the G. speciosum ethanolic extract, this study selected gastrodin as an analytical marker to control the quality of $G$. speciosum ethanolic extract. It was also used as an analytical marker for quality evaluation of Gastrodiae rhizoma extracts using RP-HPLC [13, 14, 15].



Figure 1. Basic structure of gastrodin

Therefore, in this study, RP-HPLC technique was developed to analyze the quantity of gastrodin in G. speciosum extract. The method was developed and validated according to the AOAC Guidelines for Single Laboratory Validation of Chemical Methods for Dietary Supplements and Botanicals [16]. The quantitative analysis of gastrodin, the analytical marker in G. speciosum extract by RP-HPLC technique can be utilized to monitor the quality of the plant's raw materials and may also be applied to analyze G. speciosum extract in future cosmetic formulations.

\section{Extract preparation}

\section{Materials and Methods}

Fresh pseudobulbs of G. speciosum were collected from the Khao Hin Sorn Royal Development Study Center's Area, Chachoengsao province. Dry pseudobulbs of $G$. speciosum were ground up and macerated 3 times for 3 days in ethanol $(1: 9 \mathrm{w} / \mathrm{v})$, at $25^{\circ} \mathrm{C}$. The extract was then filtered and evaporated under vacuum pressure at a temperature 
below $40{ }^{\circ} \mathrm{C}$. The extract of G. speciosum were prepared in 3 different batches (batch 1: January, batch 2: May, and batch 3: September, year 2016). Each batch was collected 4 months apart.

\section{LC-MS analysis}

The G. speciosum extract was analyzed using a Dionex Ultimate TM 3000 HPLC (Germering, Germany) coupling with Bruker Amazon SL mass spectrometer (Bremen, Germany). Acclaim 120-C18 column (2.1 x $150 \mathrm{~mm}, 3 \mu \mathrm{m}$, Thermo Fisher Scientific, Germany) was used as a stationary phase. Analysis was performed in a gradient mode using 0.1\% formic acid-acetonitrile ratio at 99:1 (0-3 minutes), gradient from 99:1 to 90:10 (3-5 minutes), gradient from 90:10 to 75:25 (5-8 minutes), gradient from 75:25 to 50:50 (8-10 minutes), gradient from 50:50 to 1:99 (10-11 minutes), isocratic at 1:99 (11-16 minutes), and re-equilibrate at 99:1 for 5 minutes. The column was maintained at $25{ }^{\circ} \mathrm{C}$ with a flow rate of $0.15 \mathrm{~mL} / \mathrm{min}$ and the injection volume was $5 \mu \mathrm{L}$. The mass spectrometer was equipped with an ESI ion source and a quadrupole-ion trap. LC-MS evaluation was performed using full scan in negative mode recorded on a mass range of $\mathrm{m} / \mathrm{z} 100-1,000$. Capillary voltage was set at 4,500 V, and drying gas temperature was $200{ }^{\circ} \mathrm{C}$ with a flow rate of $7.0 \mathrm{~L} / \mathrm{min}$. Nebulizer pressure was set at 2 bars. Gastrodin was recognized by comparing the parent and fragment ions with the reference standard using the multiple reactions monitoring (MRM) method. Data were processed by Compass 1.3 SR2 program.

\section{Instrumentation and chromatographic conditions}

Chromatographic analysis was performed using Agilent high performance liquid chromatographic system (Agilent Technologies, California, United States of America) with a quaternary pump (G1311A). An auto-sampler (Agilent G1313A) and column oven (G1316A) were used with a photodiode array detector (G 1315A). Results were acquired and evaluated by ChemStation software (Agilent Technologies, California, United States of America). Chromatography was performed under gradient conditions with a total run time of 18 minutes. The mobile phase was filtered through a $0.22-\mu \mathrm{m}$ membrane filter prior to use. The mobile phase consisted of solvent $\mathrm{A}$ (water) and solvent B (acetonitrile). The gradient started with $99 \%$ solvent A for 3 minutes, was adjusted to $90 \%$ solvent A for 2 minutes, to $75 \%$ solvent A for 3 minutes, to $50 \%$ solvent A for 2 minutes, to $100 \%$ solvent B for 4 minutes, and finally to $99 \%$ solvent A for 4 minutes. The flow rate of the system was $1.7 \mathrm{~mL} / \mathrm{min}$ with the column temperature controlled at $25^{\circ} \mathrm{C}$. The injection volume was set at $20 \mu \mathrm{l}$. DAD was adjusted at 200-380 nm with a monitoring wavelength of $220 \mathrm{~nm}$. The RP-HPLC column used was an Inertsil ODS-3 C18 (4.6 x150 mm, $5 \mu \mathrm{m})$ column. Gastrodin was found to elute at the retention time of 6.5 minutes. Gastrodin was identified by comparing the chromatogram and retention time of $G$. speciosum extract with gastrodin standard (\% purity $>98 \%$ ) (Chengdu Biopurify Phytochemicals, Sichuan, China).

\section{Calibration and method validation}

An amount $5 \mathrm{mg}$ of gastrodin standard was dissolved in $5 \mathrm{~mL}$ of ethanol $(20 \% \mathrm{w} / \mathrm{w})$ and diluted with ethanol $(20 \%$ $\mathrm{w} / \mathrm{w})$ corresponding to test ranges. Gastrodin standard solution was diluted with ethanol $(20 \% \mathrm{w} / \mathrm{w})$ to obtain final concentrations of $10,20,30,40,50,70$ and $100 \mu \mathrm{g} / \mathrm{mL}$. After filtering through a $0.22-\mu \mathrm{m}$ syringe filter, $20 \mu \mathrm{L}$ of each standard solution was injected into the RP-HPLC system. The calibration curve was constructed by plotting peak areas against the corresponding concentration of gastrodin. Each concentration was analysed in triplicate. The slope, y-intercept and $r^{2}$ were calculated using the least squares regression method. Limits of detection (LOD) and quantification (LOQ) were calculated from the calibration line at the low concentration. LOD and LOQ were calculated from the following formulas in equation 1 and 2 [17]:

$$
\begin{aligned}
& \mathrm{LOD}=3.3 \mathrm{Sy} / \mathrm{S} \\
& \mathrm{LOQ}=10 \mathrm{Sy} / \mathrm{S}
\end{aligned}
$$

where Sy is the standard deviation of the response curve and $\mathrm{S}$ is the slope of the calibration curve.

Specificity was examined by separately injecting the gastrodin standard solution at concentration of $50 \mu \mathrm{g} / \mathrm{mL}$ and G. speciosum extract solution using RP-HPLC to obtain gastrodin peak response. 


\section{Chowjarean et al: VALIDATED RP-HPLC METHOD FOR QUANTIFICATION OF GASTRODIN IN ETHANOLIC EXTRACT FROM THE PSEUDOBULBS OF Grammatophyllum speciosum Blume}

The precision of the developed method was evaluated through intraday and interday variations of gastrodin at concentration of $50 \mu \mathrm{g} / \mathrm{mL}$. The intraday precision analysis was performed in 6 replicates on samples prepared on a single day, while interday precision analysis was performed in 6 replicates on 3 different days. Accuracy was evaluated by determining the average \% recovery of analytes. Three different concentrations were prepared by accurately weighing $50 \mathrm{mg}$ of $\mathrm{G}$. speciosum extract solution into well-sealed glass containers, after which $80 \mathrm{ml}$ of ethanol $(20 \% \mathrm{w} / \mathrm{w})$ was added and the solution was sonicated for 5 minutes. A gastrodin standard solution was added to each G. speciosum extract solution sample to obtain final concentrations of 45,50 and $55 \mu \mathrm{g} / \mathrm{mL}$. Ethanol $(20 \% \mathrm{w} / \mathrm{w})$ was then added to acquire a volume of $100 \mathrm{ml}$. Each concentration was analyzed in triplicate. Average $\%$ recovery and \% relative standard deviation (\%RSD) values were calculated to determine the accuracy and precision of the system.

\section{Sample analysis}

An amount $5 \mathrm{mg}$ of $G$. speciosum extract was dissolved in $5 \mathrm{~mL}$ of ethanol $(20 \% \mathrm{w} / \mathrm{w})$. The extract mixture was then filtered through $0.22-\mu \mathrm{m}$ syringe filter, and $20 \mu \mathrm{L}$ of the resulting filtrate was injected into the RP-HPLC system. Every sample solution was analyzed in triplicate.

\section{Statistical analysis}

Results were expressed as the mean values \pm standard deviation (SD) from at least three independent experiments. The statistical comparisons were carried out using one-way ANOVA with post hoc test (SPSS, SPSS Inc., Chicago, IL, USA). Statistical significance was accepted within the 95\% confidence limit $(p<0.05)$.

\section{Results and Discussion}

To optimize the RP-HPLC condition, the tests were done under various conditions. The mobile phases were prepared using multiple proportions including water-acetonitrile or water-methanol. Among several C-18 reversedphase columns, column Inertsil ODS-3 $(4.6 \times 150 \mathrm{~mm}, 5 \mu \mathrm{m})$ was selected as the most suitable condition because of its relatively shorter running time.

For specificity, gastrodin peaks were identified with retention times comparable with the gastrodin standard and confirmed for its characteristic spectra by diode array detection (range 200-380 nm). The retention time of $G$. speciosum extract samples and standard solutions were found to elute at 6.483 and 6.494 minutes, respectively (Figure 2). In addition, the UV pattern of the extract at the retention time of 6.483 minutes was similar to the gastrodin standard (Figure 3).

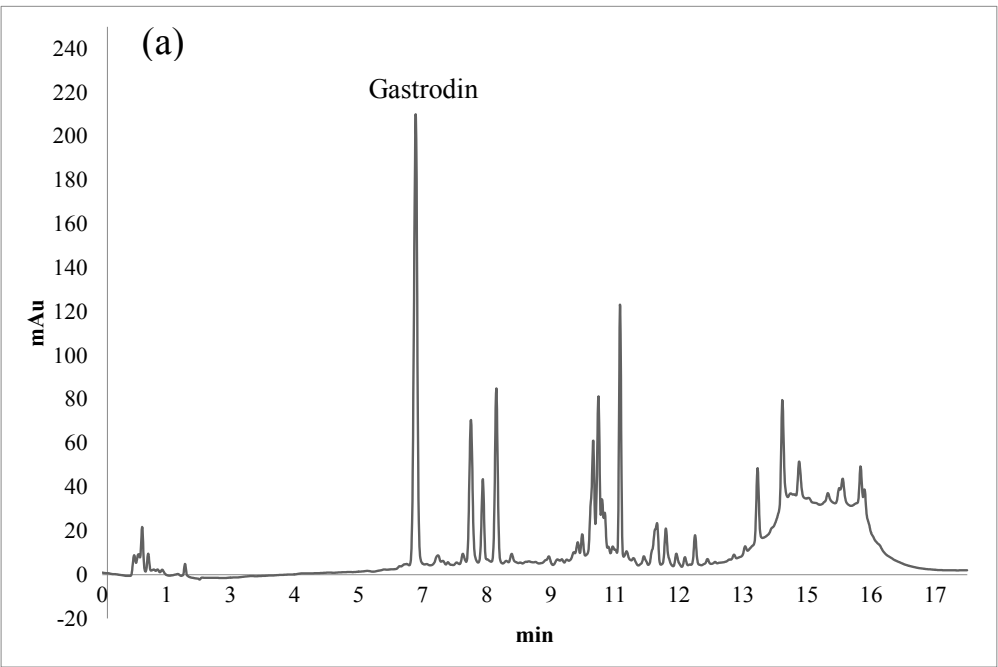




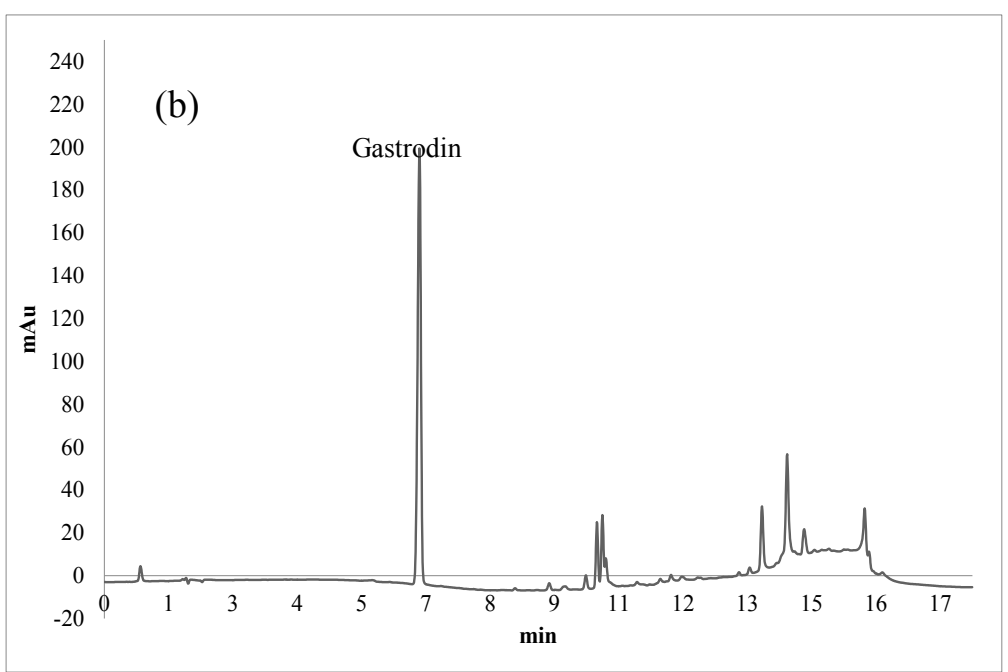

Figure 2. (a) A typical HPLC chromatogram of the G. speciosum pseudobulb ethanolic extract and (b) gastrodin standard HPLC chromatogram

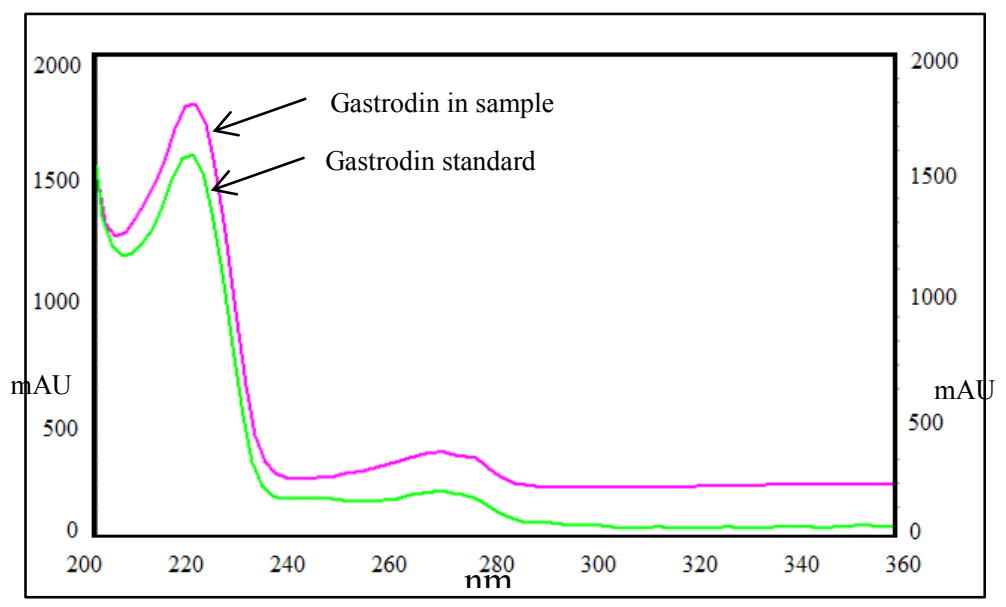

Figure 3. LC-UV absorption patterns of gastrodin in the G. speciosum Pseudobulb ethanolic extract (upper line) and gastrodin standard (lower line)

Moreover, the identification of gastrodin, an analytical marker of G. speciosum ethanolic extract, was confirmed using LC-MS technique. The mass transition was monitored in the reference and sample solutions to guarantee specificity. The molecular mass at $331.1 \mathrm{~m} / z\left([\mathrm{M}-\mathrm{H}]^{-} 331.1\right)$ of the G. speciosum extract was comparable to the gastrodin standard using formic acid addition in negative ion mode. The fragmentation pattern mass spectrum was found at 285.0, 206.8, 160.8 and $122.9 \mathrm{~m} / \mathrm{z}$ which was consistent with the previous study [14] (Figure 4). Linearity parameters of the system are shown in Table 1. The results showed that gastrodin exhibited good linearity within specified ranges with coefficient of determination $\left(\mathrm{r}^{2}\right)$ of 0.9999 . These results complied with the AOAC Guidelines, which stated that the coefficient of determination should be $>0.99$ for acceptable linearity. The regression equation was $\mathrm{y}=20.0029 \mathrm{x}+0.9758$, where $\mathrm{y}$ is the peak area and $\mathrm{x}$ is the corresponding concentration of gastrodin standard. The linear range was $10-100 \mu \mathrm{g} / \mathrm{mL}$. The calculated LOD and LOQ of gastrodin were 0.1244 and $0.3769 \mu \mathrm{g} / \mathrm{mL}$, respectively. 


\section{Chowjarean et al: VALIDATED RP-HPLC METHOD FOR QUANTIFICATION OF GASTRODIN IN ETHANOLIC EXTRACT FROM THE PSEUDOBULBS OF Grammatophyllum speciosum Blume}
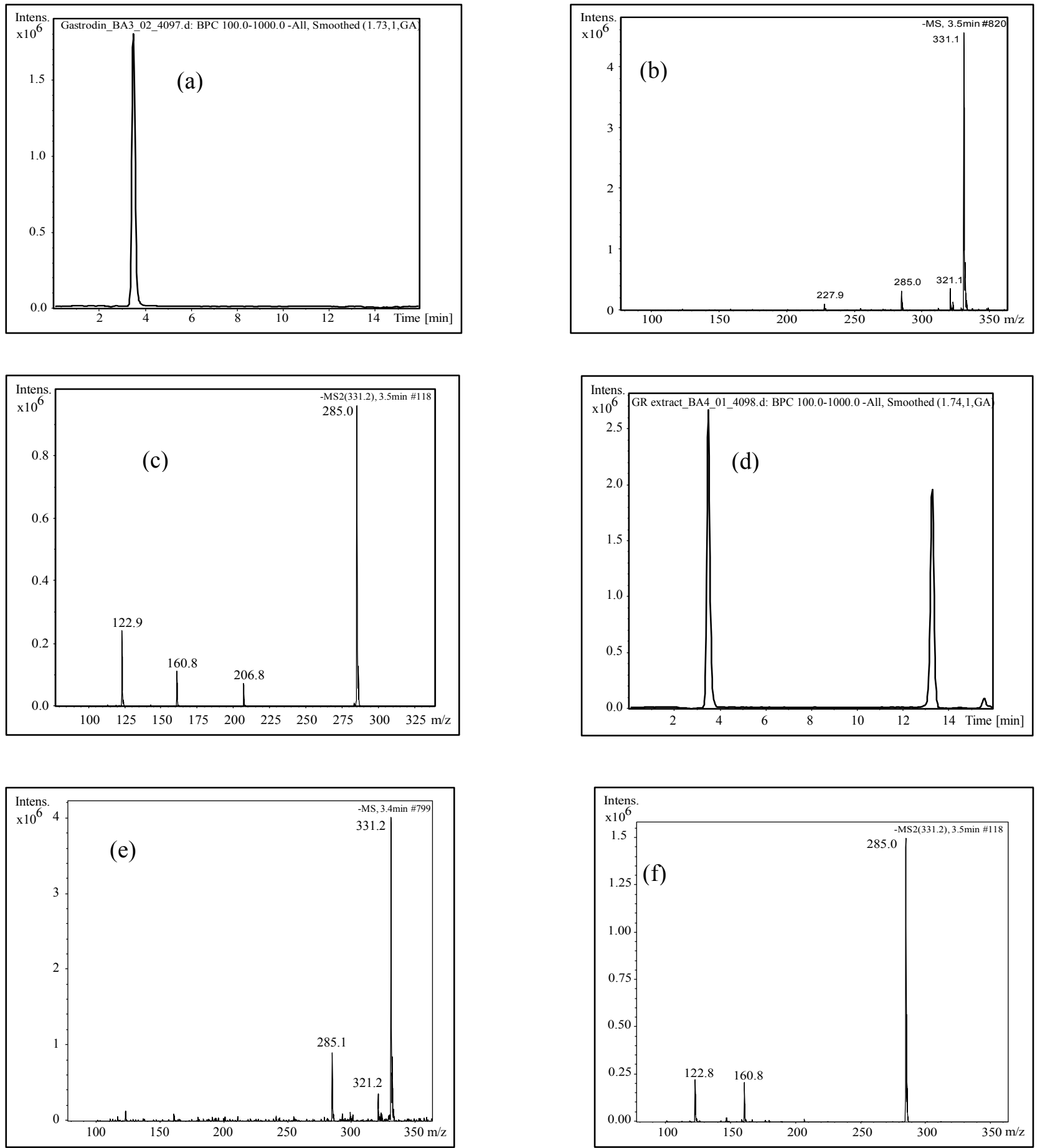

Figure 4. Typical chromatogram and MS spectra of the gastrodin (a) Base peak chromatogram of gastrodin standard $(\mathrm{Rt}=3.5 \mathrm{~min})(\mathrm{b}) \mathrm{MS}$ spectra of gastrodin standard ion [M+HCOOH-H]- (c) MS2 spectra of gastrodin standard ion $[\mathrm{M}+\mathrm{HCOOH}-\mathrm{H}]-$ at $\mathrm{m} / \mathrm{z} 331.1$ (d) Base peak chromatogram of G. speciosum extract (e) MS spectra of G. speciosum extract ion at $3.5 \mathrm{~min}$ (f) MS2 spectra of G. speciosum extract ion at $\mathrm{m} / \mathrm{z} 331.2$ 
Repeatability precision of the system is shown as a \%RD values in Table 1 . The intraday and interday precisions were 1.05 and $0.38 \%$, respectively. The repeatability results for gastrodin analytical markers showed \%RSD values of $<1.5$, which complied with the AOAC Guidelines [16]. The accuracy of the system is shown in Table 1 . The average \% recovery was found $100.14,100.54$ and 101.25 for $80 \%, 100 \%$ and $120 \%$ concentrations of gastrodin, respectively. The average \%recovery of gastrodin complied with the AOAC Guidelines, which stated that this value should be between 95-102\%. These results indicate that the developed HPLC method was accurate and precise in the determination of gastrodin in ethanolic extracts of G. speciosum.

Table 1. Validation data of gastrodin

\begin{tabular}{lc}
\hline Parameters & Gastrodin \\
\hline Linearity & \\
Range $(\mu \mathrm{g} / \mathrm{mL})$ & $10-100$ \\
Coefficient of determination $\left(\mathrm{r}^{2}\right)$ & 0.9999 \\
Equation & \\
$\quad$ Intercept & 0.9758 \\
Slope & 20.0029 \\
Precision $(50 \mu \mathrm{g} / \mathrm{mL})$ & \\
Intra-day $(\% \mathrm{RSD})$ & 1.05 \\
Inter-day $(\% \mathrm{RSD})$ & 0.38 \\
Accuracy $(\% \mathrm{Recovery})$ & \\
$80 \%(45 \mu \mathrm{g} / \mathrm{mL})$ & 100.14 \\
100\% $(50 \mu \mathrm{g} / \mathrm{mL})$ & 100.54 \\
$120 \%(55 \mu \mathrm{g} / \mathrm{mL})$ & 101.25 \\
Limit of quantitation $(\mu \mathrm{g} / \mathrm{mL})$ & 0.3769 \\
Limit of detection $(\mu \mathrm{g} / \mathrm{mL})$ & 0.1244 \\
\hline
\end{tabular}

The amount of gastrodin in 3 different batches of G. speciosum ethanolic extract was analyzed using a validated method. The results showed that the amount of gastrodin from batch 1, batch 2, and batch 3 contained 58.12 \pm 4.6 , $57.24 \pm 2.5$, and $55.50 \pm 1.4 \mathrm{mg} / \mathrm{g}$, respectively (Table 2), which was considered to be not significantly different from one another $(\mathrm{p}>0.05)$. The result thus suggested that gastrodin levels were not significantly different among batches.

Table 2. Gastrodin contents of G. speciosum pseudobulb at different batches $(\mathrm{n}=5)$

\begin{tabular}{lccc}
\hline Batch & $\mathbf{1}$ & $\mathbf{2}$ & $\mathbf{3}$ \\
\hline Gastrodin $(\mathrm{mg} / \mathrm{g})$ & $58.12 \pm 4.6$ & $57.24 \pm 2.5$ & $55.50 \pm 1.4$ \\
\hline
\end{tabular}

\section{Conclusion}

This developed HPLC method agreed well with AOAC Guidelines for Single-Laboratory Validation of Chemical Methods for Dietary Supplements and Botanicals which can be effectively used for the quality control of $G$. speciosum extracts and can be applied for quantification of gastrodin in future cosmetic products. Further studies on the determinations of gastrodin contents from all varieties and sources of G. speciosum will be worthwhile in establishing a quality control database.

\section{Acknowledgement}

This research was supported by grant no. CDRT-1600-01-2016 from supported by Cosmeceutical Research, Development and Testing Center, Faculty of Pharmacy, Rangsit University, Thailand. The authors wish to thank the Faculty of Pharmacy of Rangsit University for providing the research facilities. 


\section{References}

1. Nontachaiyapoom, S., Sasirat, S. and Manoch, L. (2011). Symbiotic seed germination of Grammatophyllum speciosum Blume and Dendrobium draconis Rchb. f., native orchids of Thailand. Scienta Horticultuae, 130(1): 303 - 308.

2. Sahakitpichan, P., Mahidol, C., Disadee, W., Chimnoi, N., Ruchirawat, S. and Kanchanapoom, T. (2013). Glucopyranosyloxybenzyl derivatives of (R)-2-benzylmalic acid and (R)-eucomic acid, and an aromatic glucoside from the pseudobulbs of Grammatophyllum speciosum. Tetrahedron, 69(3): 1031 - 1037.

3. Uawonggul, N., Chaveerach, A., Thammasirirak, S., Arkaravichien, T., Chuachan, C. and Daduang, S. (2006). Screening of plants acting against Heterometrus laoticus scorpion venom activity on fibroblast cell lysis. Journal of Ethnopharmacology, 103 (2): 201 - 207.

4. Kumar, H., Kim, I. S., More, S. V., Kim, B. W., Bahk, Y. Y. and Choi, D. K. (2013). Gastrodin protects apoptotic dopaminergic neurons in a toxin-induced Parkinson's disease model. Journal of Evidence-Based Complementary and Alternative Medicine, 2013: 1 - 14.

5. Hsieh, M. T., Wu, C. R. and Chen, C. F. (1997). Gastrodin and p-hydroxybenzyl alcohol facilitate memory consolidation and retrieval, but not acquisition, on the passive avoidance task in rats. Journal of Ethnopharmacology, 56(1): 45 - 54.

6. Wu, C. R., Hsieh, M. T., Huang, S. C., Peng, W. H., Chang, Y. S. and Chen, C. F. (1996). Effects of Gastrodia elata and its active constituents on scopolamine-induced amnesia in rats. Planta Medica, 62 (4): 317 - 321.

7. An, S. J., Park, S. K., Hwang, I. K., Choi, S. Y., Kim, S. K., Kwon, O. S., Jung, S. J., Baek, N. I., Lee, H. Y. and Won, M. H. (2003). Gastrodin decreases immunoreactivities of $\gamma$-aminobutyric acid shunt enzymes in the hippocampus of seizure-sensitive gerbils. Journal of Neuroscience Research, 71(4): 534 - 543.

8. Kim, H. J., Moon, K. D., Lee, D. S. and Lee, S. H. (2003). Ethyl ether fraction of Gastrodia elata Blume protects amyloid $\beta$ peptide-induced cell death. Journal of Ethnopharmacology, 84(1): 95 - 98.

9. Hu, Y., Li, C. and Shen, W. (2014). Gastrodin alleviates memory deficits and reduces neuropathology in a mouse model of Alzheimer's disease. Neuropathology, 34(4): 370 - 377.

10. Wang, X. L., Xing, G. H., Hong, B., Li, X. M., Zou, Y., Zhang, X. J. and Dong, M. X. (2014). Gastrodin prevents motor deficits and oxidative stress in the MPTP mouse model of Parkinson's disease: Involvement of ERK1/2-Nrf2 signaling pathway. Life Sciences, 114(2): 77 - 85.

11. Huang, Q., Shi, J., Gao, B., Zhang, H. Y., Fan, J., Li, X. J., Fan, J. Z., Han, Y. H., Zhang, J. K. and Yang, L. (2015). Gastrodin: an ancient Chinese herbal medicine as a source for anti-osteoporosis agents via reducing reactive oxygen species. Bone, 73: 132 - 144.

12. Chowjarean, V., Nimmannit, U., Chaotham, C., Eaknai, W., Sucontphunt, A., Plaimee, P. P., Tengamnuay, P. and Chanvorachote, P. (2017). Grammatophyllum speciosum extract potentiates stemness in keratinocyte cells. Chiang Mai Journal of Science, 45 (1): 237 - 248.

13. Chen, W. C., Lai, Y. S., Lu, K. H., Lin, S. H., Liao, L. Y., Ho, C. T. and Sheen, L. Y. (2015). Method development and validation for the high-performance liquid chromatography assay of gastrodin in water extracts from different sources of Gastrodia elata Blume. Journal of Food and Drug Analysis, 23 (4): 803 810 .

14. Jia, Y., L,i X., Xie, H., Shen, J., Luo, J., Wang, J., Wang, K. D., Liu, Q. and Kong, L. (2014). Analysis and pharmacokinetics studies of gastrodin and $p$-hydroxybenzyl alcohol in dogs using ultra fast liquid chromatography-tandem mass spectrometry method. Journal of Pharmaceutical and Biomedical Analysis, 99: 83 - 88 .

15. Lee, J-G., Moon, S-O., Kim, S-Y., Yang, E-J., Min, J-S., An, J-H., Choi, E-A., Liu, K-H., Park, E. J. and Lee, H-D. (2015). Rapid HPLC determination of gastrodin in Gastrodiae Rhizoma. Applied Biological Chemistry, 58 (3): $409-413$.

16. AOAC Official Methods of Analysis (2013). Appendix K: Guideline for dietary supplements and botanicals. http://www.eoma.aoac.org/app_k.pdf. [Accessed online 29 June 2017].

17. Shrivastava, A. and Gupta, V. B. (2011). Methods for the determination of limit of detection and limit of quantitation of the analytical methods. Chronicles of Young Scientists, 2(1): 21 - 21. 